\title{
KEBIJAKAN PENGEMBANGAN PARIWISATA DI KALIMANTAN TENGAH \\ (Studi Terhadap Pelaksanaan Program Pembangunan Destinasi dan Pembangunan Pemasaran Pariwisata di Dinas Kebudayaan dan Pariwisata Provinsi Kalimantan Tengah)
}

\author{
Raesha Aprilia Rangin
}

\begin{abstract}
ABSTRAK
Pembangunan pariwisata di Kalimantan Tengah berlangsung setidaknya pada satu dekade terakhir ini. Pembangunan pariwisata dilaksanakan mengacu pada UU No. 10 Tahun 2009 tentang Kepariwisataan, PP No. 50 Tahun 2011 tentang Ripparnas, dan Perda Provinsi Kalteng No. 2 Tahun 2013 tentang Ripparprov. Keberadaan Ripparprov sangat dibutuhkan guna memperjelas arah kebijakan pembangunan pariwisata di Kalimantan Tengah. Sebelum Ripparprov terbentuk pembangunan pariwisata Kalteng terkesan jalan ditempat dan berlangsung sporadis. Penelitian ini bertujuan untuk: 1) untuk mengkaji dan mendeskripsikan pelaksanaan program pembangunan destinasi dan pemasaran pariwisata Kalimantan Tengah oleh Dinas Kebudayaan dan Pariwisata. 2) Untuk mengkaji dan mendeskripsikan faktor penghambat dan faktor pendorong pelaksanaan program pembangunan destinasi dan pemasaran pariwisata Kalimantan Tengah oleh Dinas Kebudayaan dan Pariwisata. Jenis penelitian yang digunakan adalah deskriptif dengan menggunakan data-data kualitatif sebagai bahan utama kajian. Data dikumpulkan melalui teknis wawancara terstruktur, observasi, dan dokumentasi. Teknik analisis data menggunakan model Miles and Huberman. Berdasarkan hasil penelitian dan temuan di lapangan menunjukkan fakta-fakta sebagai berikut: 1) Komunikasi, pola komunikasi kebijakan berlangsung secara formal kedinasan dari atasan ke bawahan. 2) Sumber daya, SDM dan anggaran tersedia dalam jumlah terbatas dan didukung oleh payung hukum yang jelas. 3) Struktur Birokrasi, telah didukung oleh SOP khususnya dalam pembangunan pemasaran, untuk pembangunan destinasi masih belum tersedia. 4) Disposisi, pengangkatan birokrat menjadi kewenangan Kepala Daerah, insentif hanya diberikan kepada pelaku usaha yang berkontribusi terhadap pembangunan pariwisata. Tidak tersedia insentif bagi implementor kebijakan (birokrat).
\end{abstract}

Kata Kunci: Pariwisata, Pembangunan, Destinasi, Pemasaran

\section{PENDAHULUAN}

Undang-Undang Nomor 10 Tahun 2009 tentang Kepariwisataan menyatakan bahwa kepariwisataan merupakan bagian integral dari Pembangunan Nasional yang dilakukan secara sistematis, terencana, terpadu, berkelanjutan, dan bertanggung jawab dengan tetap memberikan perlindungan terhadap nilai-nilai agama, budaya yang hidup dalam masyarakat, kelestarian dan mutu lingkungan hidup serta kepentingan nasional. Itu sebabnya kepariwisataan perlu dibangun dan dikembangkan secara efektif di suatu Negara.

Pembangunan Nasional merupakan upaya pemerintah dalam mencapai tujuan Negara. Upaya-upaya yang dilakukan adalah dengan menetapkan kebijakan mengenai kepariwisataan yang bekesinambungan dengan kepentingan nasional. Kebijakan dalam pembangunan dan pengembangan sektor pariwisata ini meliputi beberapa hal penting dua dari empat pembangunan kepariwisataan yang tercantum pada Peraturan Daerah Provinsi Kalimantan Tengah yaitu destinasi pariwisata dan pemasaran pariwisata. Pada pelaksanaannya pemerintah yang memiliki tanggung jawab melaksanakannya. Dengan begitu pemerintah diharapkan mampu menjalankan fungsi, tugas, dan tanggung jawab sebagai pelaksana kebijakan secara 
efektif. Pemerintah sebagai pembuat kebijakan harus mampu memberikan kontibusi berupa unsur-unsur rasional dan mengimbangi kelemahan-kelemahan dalam pemerintah begitu pula dalam mengatasi permasalahan yang akan muncul dari kebijakan tersebut.

Kebijakan apabila dilaksanakan dengan tepat akan memperoleh hasil yang baik pula. Namun banyak faktor yang akan mempengaruhi keberhasilan bahkan sampai pada kegagalan kebijakan.

Saat ini sektor pariwisata telah membawa dampak sosial, ekonomi, maupun dalam pelestarian dan pengelolaan lingkungan, sumber daya alam. Kegiatan pariwisata juga berperan penting dalam proses pembangunan dan pengembangan wilayah-wilayah yang memiliki potensi wisata. Dan juga kegiatan pariwisata telah memberikan sumbangan besar bagi pendapatan suatu daerah maupun masyarakat. Meski sektor pariwisata berdampak positif bagi daerah maupun masyarakat akan tetapi pemerintah tidak dapat terhindar dari masalah-masalah yang muncul akibat kegiatan pariwisata. Seperti implementasi kebijakan pariwisata yang masih sangat jauh dari keberhasilannya.

Implementasi kebijakan yang terhambat sedang dihadapi oleh pemerintah Provinsi Kalimantan Tengah khususnya sektor pariwisata dengan pusat perkembangan di wilayah tengah Palangka Raya. Dimana implementasi kebijakan destinasi dan pemasaran pariwisata belum secara serius dilakukan. Banyak fakta di lapangan yang menunjukkan bahwa pembangunan destinasi pariwisata belum dilakukan dengan optimal. Begitu juga dengan persoalan pemasaran. Tinjauan dilapangan menunjukkan cukup banyak destinasi wisata di Kalimantan Tengah sebagai contoh di Kota Palangka Raya belum tersosialisasi dengan baik kepada masyarakat. Hal ini menyebabkan banyak masyarakat Kota Palangka Raya yang memanfaatkan waktu liburnya untuk berwisata keluar kota yakni ke Kota Banjarmasin Kalimantan Selatan. Hal ini tentu sangat disayangkan sekali, karena masyarakat Kota Palangka Raya seharusnya dapat menikmati wisata didalam kota dan juga berkontribusi kepada Pendapatan Asli Daerah (PAD), yang menikmati kontribusi malah pemerintah daerah diluar Provinsi Kalimantan Tengah.

Sebagai sebuah daerah otonom Pemerintah Provinsi Kalimantan Tengah telah memiliki kebijakan berupa Peraturan Daerah (Perda) Provinsi Kalimantan Tengah Nomor 2 Tahun 2013 tentang Rencana Induk Pembangunan Kepariwisataan Kalimantan Tengah Tahun 2013-2018. Kebijakan ini telah berlaku sejak bulan Mei tahun 2013. Dengan demikian sudah kurang lebih 2 (dua) tahun Perda tersebut telah diimplementasikan.

Seiring berjalannya waktu implementasi Perda tersebut seyogyanya disambut dengan baik oleh seluruh pemerintah daerah kabupaten/kota di Kalimantan Tengah. Akan tetapi sepertinya hal tersebut tidak terjadi. Informasi yang berkembang di lapangan menunjukkan tidak satupun pemerintah daerah kabupaten/kota menyambut kebijakan pemerintah provinsi untuk meningkatkan pembangunan kepariwisataan di masing-masing wilayahnya. Dukungan pemerintah kabupaten/kota tersebut seharusnya dapat ditunjukkan dengan menyusun dan membentuk peraturan daerah turunan yang mengatur tentang Rencana Induk Pembangunan Kepariwisataan Kabupaten/Kota. Sektor pariwisata sepertinya belum menjadi perhatian dan primadona bagi pemerintah kabupaten/kota. Hal tersebut tentu sangat disayangkan sekali, jika mempertimbangkan potensi wisata yang begitu besar yang dimiliki oleh masing-masing daerah kabupaten/kota di Kalimantan Tengah.

Waktu terus berjalan, keadaan demikian cukup mempengaruhi terhadap pembangunan destinasi dan pemasaran di Kalimantan Tengah. Beberapa destinasi wisata di Kalimantan Tengah masih belum dikelola dengan baik. Ada beberapa wisata alam yang hanya dikelola dengan sekedarnya. Bahkan pihak yang mengelola bukan pemerintah tetapi kelompok masyarakat. Diduga kelompok masyarakat-lah yang mendapatkan keuntungan dari pengelolaan destinasi wisata, contoh kasus di Taman Alam Bukit Tangkiling Kota Palangka Raya. Di objek wisata tersebut pemerintah hadir hanya untuk membangun infrastruktur jalan 
dan tangga untuk arena berjalan selebihnya yang mengurus dan mengelola adalah masyarakat. Selanjutnya pemerintah daerah kurang mendapat kontribusi dari masyarakat yang berkunjung ke daerah tersebut. Di beberapa lokasi lain seperti objek wisata Nyaru Menteng Kota Palangka Raya, pemerintah daerah hanya mampu membangun plang atau baliho yang memberikan nama atas objek wisata tersebut. Padahal kebutuhan objek wisata sebagai sebuah destinasi wisata lebih dari itu. Perlu adanya fasilitas-fasilitas penunjang lain yang dapat mendorong masyarakat untuk mau berkunjung ke objek wisata tersebut. Sarana pendukung seperti tempat penginapan yang layak, kantin, tempat hiburan anak, toilet yang bersih, penerangan yang cukup, keamanan dan lain sebagainya masih belum dihadirkan oleh pemerintah daerah setempat.

Permasalahan dalam hal pemasaran yang sering terdengar oleh masyarakat adalah bahwa Pemerintah Provinsi Kalimantan Tengah cukup santer mempromosikan destinasi pariwisata Kalimantan Tengah melalui berbagai cara seperti mengadakan Festival Budaya Isen Mulang yang diadakan setiap tahun di bulan Mei, promosi melalui cetak brosur dan pamflet yang disebar pada saat pameran di tingkat nasional, promosi melalui website resmi Kalimantan Tengah, dan lain sebagainya. Akan tetapi hal tersebut masih belum optimal karena ternyata tingkat kunjungan wisatawan ke Kalimantan Tengah masih mengalami pasang surut dalam perkembangannya. Berikut data yang dapat dihimpun:

Tabel 1.1

Tingkat Kunjungan Wisatawan Mancanegara Ke Kalimantan Tengah

\begin{tabular}{|c|c|}
\hline Tahun & Jumlah Kunjungan (orang)/tahun \\
\hline 2005 & $1.000 \mathrm{~s} / \mathrm{d} 2.300$ \\
\hline 2006 & $1.000 \mathrm{~s} / \mathrm{d} 2.300$ \\
\hline 2007 & $1.000 \mathrm{~s} / \mathrm{d} 2.300$ \\
\hline 2008 & $1.000 \mathrm{~s} / \mathrm{d} 2.300$ \\
\hline 2009 & $1.000 \mathrm{~s} / \mathrm{d} 2.300$ \\
\hline 2010 & 6.380 \\
\hline 2011 & 6.671 \\
\hline 2012 & $>7.000$ \\
\hline 2013 & $>7.000$ \\
\hline 2014 & 10.724 \\
\hline
\end{tabular}

Sumber: Disbudpar, Kalteng

Berdasarkan data tersebut diatas nampak bahwa perkembangan tingkat kunjungan wisatawan mancanegara mengalami peningkatan baru sekitar 1 tahun terakhir. Hal itupun hanya mengandalkan satu destinasi wisata unggulan Kalimantan Tengah yakni Taman Nasional Tanjung Puting yang berada di Kotawaringin Barat. Sedangkan destinasi wisata yang lain masih belum menjadi perhatian dan unggulan dari Pemerintah Provinsi Kalimantan Tengah.

Berdasarkan latarbelakang sebagaimana diuraikan diatas, maka penulis sangat tertarik untuk mengkaji sejauhmana Peraturan Daerah Provinsi Kalimantan Tengah Nomor 2 Tahun 2013 telah diimplementasikan khususnya dalam hal pembangunan destinasi dan pemasaran pariwisata. Untuk itu penulis mengajukan usul judul penelitian: "KEBIJAKAN PENGEMBANGAN PARIWISATA DI KALIMANTAN TENGAH (Studi Terhadap Pelaksanaan Program Pembangunan Destinasi dan Pemasaran Pariwisata di Dinas Kebudayaan dan Pariwisata Kalimantan Tengah)"

\section{Tujuan Penelitian}

Adapun tujuan yang hendak dicapai melalui penulisan ini adalah sebagai berikut:

1. Untuk mengkaji dan mendeskripsikan pelaksanaan program pembangunan destinasi dan pemasaran pariwisata Kalimantan Tengah oleh Dinas Kebudayaan dan Pariwisata. 
2. Untuk mengkaji dan mendeskripsikan faktor penghambat dan faktor pendorong pelaksanaan program pembangunan destinasi dan pemasaran pariwisata Kalimantan Tengah oleh Dinas Kebudayaan dan Pariwisata.

\section{TINJAUAN PUSTAKA}

\section{Konsep Tentang Kebijakan Publik}

Kebijakan publik melingkupi bagian pemerintah dan masyarakat. Carl Friedrich, (dalam Agustino, 2012:7) mengemukakan kebijakan publik adalah serangkaian tindakan/kegiatan yang diusulkan oleh seseorang, kelompok, atau pemerintah dalam suatu lingkungan tertentu dimana terdapat hambatan-hambatan (kesulitan-kesulitan) dan kemungkinan-kemungkinan (kesempatan-kesempatan) dimana kebijakan tersebut diusulkan agar berguna dalam mengatasinya dan untuk mencapai tujuan yang dimaksud. Friedrich juga menambahkan ketentuannya bahwa kebijakan tersebut berhubungan dengan penyelesaian maksud dan tujuan.

Pengertian diatas tidak jauh berbeda dengan yang diungkapkan James Anderson (dalam Agustino, 2012:7) bahwa kebijakan publik adalah serangkaian kegiatan yang mempunyai maksud/tujuan tertentu yang diikuti dan dilaksanakan oleh seseorang actor atau sekelompok aktor yang berhubungan dengan suatu permasalahan atau suatu hal yang diperhatikan. Kebijakan publik disebut juga dengan kebijakan pemerintah. Rian Nugroho (2009:92) mengungkapkan bahwa kebijakan publik adalah keputusan yang dibuat oleh Negara, khususnya pemerintah sebagai strategi untuk merealisasikan tujuan Negara yang bersangkutan. Secara singkat kebijakan adalah apa yang dikerjakan pemerintah. Pemerintah sendiri mencakup seluruh organisasi negara, baik itu MPR, DPR, DPD, Presiden, BPK, MA, dan Pemerintah Daerah. Dari pengertian tersebut dapat dipahami bahwa kebijakan publik menjadi suatu respon terhadap keadaan. Jadi, kebijakan publik adalah suatu keputusan pemerintah dengan maksud untuk mengatur dan mengatasi masalah tertentu maupun dalam pencapaian tujuan.

Kebijakan publik sebagaimana yang telah digambarkan tidak begitu saja lahir, namun melalui proses atau tahap yang cukup panjang. Penjelasan tersebut menyatakan bahwa kebijakan memerlukan proses dan tahapan. Agar memperoleh kebijakan yang tepat dan dapat sesuai dengan sasaran dan tujuan yang akan dicapai. Jadi setiap proses kebijakan perlu dilakukan analisis kebijakan.

Analisis kebijakan publik meliputi formulasi, implemntasi, dan evaluasi. Kridawati (2011:83-85), menyatakan bahwa metodologi analisis kebijakan publik diambil dan dipadukan dari berbagai elemen-elemen disiplin ilmu: politik, sosiologi, psikologi, ekonomi, dan filsafat. Analisis kebijakan yang bersifat deskriptif yang mencari pengetahuan tentang sebab dan akibat dari kebijakan publik. Selain itu, analisis kebijakan bersifat normatif yang tujuannya adalah menciptakan dan melakukan kritik terhadap klaim pengetahuan tentang nilai kebijakan publik untuk generasi masa lalu, masa kini, dan masa mendatang.

Dunn (dalam Kridawati, 2011:83-85) menggambarkan proses analisis kebijakan publik : (a) Problem Structuring, menganalisis sifat masalah dan potensi pemecahannya ; (b) Policy Problem adalah kebutuhan, nilai, atau keinginan yang belum terpenuhi yang hanya bias dicapai lewat pelaksanaan kebijakan; (c). Forecasting, menganalisis ramalan kemungkinan dampak yang akan terjadi di masa mendatang atas serangkaian tindakan kebijakan; (d). Policy Alternative, serangkaian tindakan yang secara potensial dapat memberikan kontribusi bagi pencapaian tujuan dan pemecahan masalah kebijakan; (e). Recommendation, menganalisis kemungkinan konsekuensi yang bakal terjadi atas serangkaian tindakan yang diambil beserta usulan pemberian nilai/harganya; (f). Policy Action, serangkaian tindakan yang dilandaskan pada alternatife kebijakan yang dirancang untuk mencapai nnilai tertentu dan memecakan 
masalah kebijakan; (g). Monitoring, menganalisis informasi tentang sebab-debab dan akibatakibat kebijakan yang telah berjalan atau terimplementasi ; (h). Policy Outcomes, dampak/konsekwensi yang timbul akibat adanya pelaksanaan kebijakan; (i). Evaluation, menganalisis informasi tentang nilai/harga dari pelaksanaan suatu kebijakan; (j). policy performance, tingkat sejauh mana dampak kebijakan telah memberikan kontribusi pada pencapaian nilai dan masalahnya terpecahkan; (k). Practical Inference, menganalisis kesimpulan kinerja kebijakan sejauh mana masalah kebijakan telah terpecahkan.

Keseluruhan tahapan dan prosedur, komponen pendukung kebijakan, konsekunesi serta dampak kebijakan merupakan pembahasan mengenai kebijakan publik.

\section{Model Implementasi Kebijakan Publik}

Model implementasi kebijakan ketiga yang berperspektif top down dikembangkan oleh George C. Edward III dalam Agustino (2008). Edward III menamakan model implementasi kebijakan publiknya dengan Direct and Indirect Impact on Implementation. Dalam pendekatan yang diteoremakan oleh keberhasilan implementasi suatu kebijakan, yaitu:

1. Komunikasi;

2. Sumberdaya;

3. Disposisi;

4. Struktur birokrasi.

Gambar 2.1

Model Pendekatan Direct and Indirect on Implementation

(George Edward III)

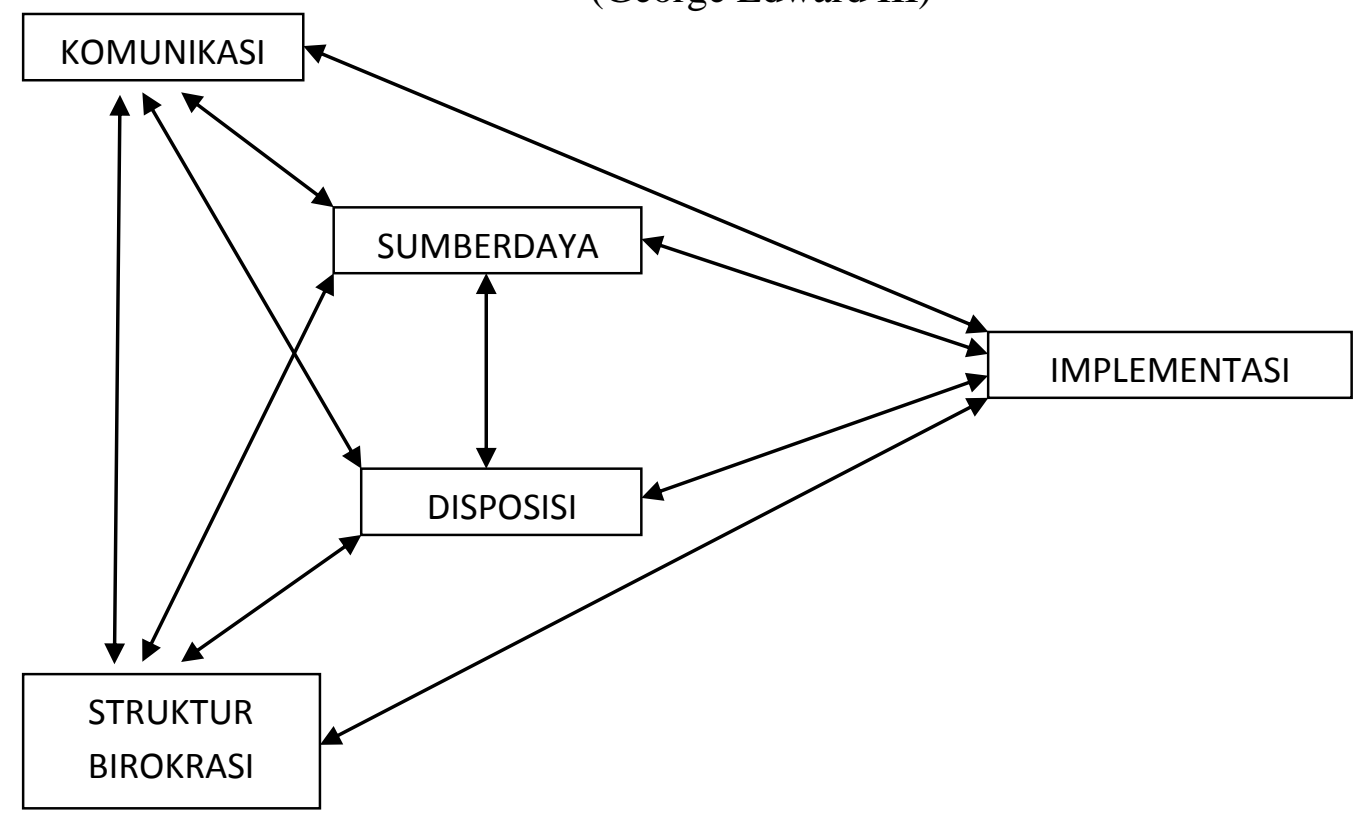

Variabel pertama yang mempengaruhi keberhasilan implementasi suatu kebijakan, menurut George C. Edward III, adalah komunikasi. Komunikasi, menurutnya lebih lanjut sangat menentukan keberhasilan pencapaian tujuan dari implementasi kebijakan publik. Implementasi yang efektif terjadi apabila para pembuat keputusan sudah mengetahui apa yang akan mereka kerjakan. Pengetahuan atas apa yang akan mereka kerjakan dapat berjalan bila komunikasi berjalan dengan baik, sehingga setiap keputusan kebijakan dan peraturan implementasi harus ditransmisikan (atau dikomunikasikan) kepada bagian personalia yang tepat. Selain itu, kebijakan yang dikomunikasikan pun harus tepat, akurat, dan konsisten. Komunikasi (atau pentransmisian informasi) diperlukan agar para pembuat keputusan dan para 
implementator akan semakin konsisten dalam melaksanakan setiap kebijakan yang akan diterapkan dalam masyarakat.

Terdapat tiga indikator yang dapat dipakai (atau digunakan) dalam mengukur keberhasilan variabel komunikasi tersebut diatas, yaitu:

a. Transmisi, penyaluran komunikasi yang baik akan dapat menghasilkan suatu implementasi yang baik pula. Seringkali yang terjadi dalam penyaluran komunikasi adalah adanya salah pengertian (miskomunikasi), hal tersebut disebabkan karena komunikasi telah melalui beberapa tingkatan birokrasi, sehingga apa yang diharapkan terdistorsi ditengah jalan.

b. Kejelasan, komunikasi yang diterima oleh para pelaksana kebijakan (street-levelbureuacrats) haruslah jelas dan tidak membingungkan (tidak ambigu/mendua). Ketidakjelasan pesan kebijakan tidak selalu menghalangi implementasi, pada tataran tertentu, para pelaksana membutuhkan fleksibilitas dalam melaksanakan kebijakan. Tetapi pada tataran yang lain hal tersebut akan menyelewengkan tujuan yang hendak dicapai oleh kebijakan yang telah ditetapkan.

c. Konsistensi, perintah yang diberikan dalam pelaksanaan suatu komunikasi haruslah konsisten dan jelas (untuk diterapkan atau dijalankan). Karena jika perintah yang diberikan sering berubah-ubah, maka dapat menimbulkan kebingungan bagi pelaksana di lapangan.

Variabel atau faktor kedua yang mempengaruhi keberhasilan implementasi suatu kebijakan adalah sumberdaya. Sumberdaya merupakan hal penting lainnya, menurut George C. Edward III, dalam mengimplementasikan kebijakan. Indikator sumber-sumberdaya terdiri dari beberapa elemen, yaitu:

a. Staff, sumberdaya utama dalam implementasi kebijakan adalah staf. Kegagalan yang sering terjadi dalam implementasi kebijakan salah satunya disebabkan oleh karena staf yang tidak mencukupi, memadai, ataupun tidak kompeten dibidangnya. Penambahan jumlah staf dan implementator saja tidak mencukupi, tetapi diperlukan pula kecukupan staf dengan keahlian dan kemampuan yang diperlukan (kompeten dan kapabel) dalam mengimplementasikan kebijakan atau melaksanakan tugas yang diinginkan oleh kebijakan itu sendiri.

b. Informasi, dalam implementasi kebijakan, informasi mempunyai dua bentuk, yaitu pertama informasi yang berhubungan dengan cara melaksanakan kebijakan. Implementator harus mengetahui apa yang harus mereka lakukan disaat mereka diberi perintah utuk melakukan tindakan. Kedua, informasi mengenai data kepatuhan dari para pelaksana terhadap peraturan dan regulasi pemerintah yang telah ditetapkan. Implementator harus mengetahui apakah orang lain yang terlibat di dalam pelaksanaan kebijakan tersebut patuh terhadap hukum.

c. Wewenang, pada umumnya kewenangan harus bersifat formal agar perintah dapat dilaksanakan. Kewenangan merupakan otoritas atau legitimasi bagi para pelaksana dalam melaksanakan kebijakan yang ditetapkan secara politik. Ketika wewenang nihil, maka kekuatan para implementator dimata publik tidak terlegitimasi, sehingga dapat menggagalkan proses implementasi kebijakan.

Tetapi dalam konteks yang lain, ketika wewenang formal tersebut ada, maka sering terjadi kesalahan dalam melihat efektivitas kewenangan. Di satu pihak, efektivitas kewenangan diperlukan dalam pelaksanaan implementasi kebijakan; tetapi disisi lain, efektivitas akan menyurut manakala wewenang diselewengkan oleh para pelaksana demi kepentingannya.

d. Fasilitas, fasilitas fisik juga merupakan faktor penting dalam implementasi kebijakan. Implementator mungkin memiliki staf yang mencukupi, mengerti apa yang harus dilakukannya, dan memiliki wewenang untuk melaksanakan tugasnya, tetapi tanpa adanya fasilitas pendukung (sarana dan prasarana) maka implementasi kebijakan tersebut tidak akan berhasil.

Variabel ketiga yang mempengaruhi tingkat keberhasilan implementasi kebijakan publik, bagi George C. Edward III, adalah disposisi. Disposisi atau sikap dari pelaksana mengenai pelaksanaan suatu pelaksanaan kebijakan publik. Jika pelaksanaan suatu kebijakan 
ingin efektif, maka para pelaksana kebijakan tidak hanya harus mengetahui apa yang akan dilakukan tetapi juga harus memiliki kemampuan untuk melaksanakannya, sehingga dalam praktiknya tidak terjadi bias.

Hal-hal penting yang perlu dicermati pada variabel disposisi menurut George C. Edward III, adalah:

a. Pengangkatan birokrat, disposisi atau sikap para pelaksana akan menimbulkan hambatanhambatan yang nyata terhadap implementasi kebijakan bila personil yang ada tidak melaksanakan kebijakan-kebijakan yang diinginkan oleh pejabat-pejabat tinggi. Karena itu, pemilihan dan pengangkatan personil pelaksana kebijakan haruslah orang-orang yang memiliki dedikasi pada kebijakan yang telah ditetapkan; lebih khusus lagi pada kepentingan warga.

b. Insentif, Edward menyatakan bahwa salah satu teknik yang disarankan untuk mengatasi masalah kecenderungan para pelaksana adalah dengan memanipulasi insentif. Oleh karena itu, pada umumnya orang bertindak menurut kepentingan mereka sendiri, maka memanipulasi insentif oleh para pembuat kebijakan mempengaruhi tindakan para pelaksana kebijakan. Dengan cara menambah keuntungan atau biaya tertentu mungkin akan menjadi faktor pendorong yang membuat para pelaksana kebijakan melaksanakan perintah dengan baik. Hal ini dilakukan sebagai upaya memenuhi kepentingan pribadi (self interest) atau organisasi.

Variabel keempat, menurut Edward III, yang mempengaruhi tingkat keberhasilan implementasi kebijakan publik adalah struktur birokrasi. Walaupun sumber-sumber untuk melaksanakan suatu kebijakan tersedia, atau para pelaksana kebijakan mengetahui apa yang seharusnya dilakukan, dan mempunyai keinginan untuk melaksanakan suatu kebijakan, kemungkinan kebijakan tersebut tidak dapat terlaksana atau terealisasi karena terdapatnya kelemahan dalam struktur birokrasi. Kebijakan yang begitu kompleks menuntut adanya kerjasama banyak orang, ketika struktur birokrasi tidak kondusif pada kebijakan yang tersedia, maka hal ini akan menyebabkan sumberdaya-sumberdaya menjadi tidak efektif dan menghambat jalannya kebijakan. Birokrasi sebagai pelaksana sebuah kebijakan harus dapat mendukung kebijakan yang telah diputuskan secara politik dengan jalan melakukan koordinasi dengan baik.

Dua karakteristik, menurut Edward III, yang dapat mendongkrak kinerja struktur birokrasi/organisasi kearah yang lebih baik adalah: melakukan Standar Operating Procedures (SOPs) dan melaksanakan fragmentasi. SOPs adalah suatu kegiatan rutin yang memungkinkan para pegawai (atau pelaksana kebijakan/administratur/birokrat) untuk melaksanakan kegiatankegiatannya pada tiap harinya sesuai dengan standar yang ditetapkan (atau standar minimum yang dibutuhkan warga). Sedangkan pelaksanaan fragmentasi adalah upaya penyebaran tanggung jawab kegiatan-kegiatan atau aktivitas-aktivitas pegawai diantara beberapa unit kerja.

\section{Pariwisata}

\section{Konsep Pariwisata}

Pariwisata berhubungan erat dengan pengertian perjalanan wisata, yaitu sebagai suatu perubahan tempat tinggal sementara seseorang diluar tempat tinggalnya karena suatu alasan dan bukan untuk melakukan kegiatan yang menghasilkan atau mencari nafkah. Orang yang melakukan perjalanan disebut traveler, sedangkan orang melakukan perjalanan untuk tujuan wisata disebut tourist.

Istilah kepariwisataan berasal dari akar kata "wisata". Dalam kepustakaan tentang kepariwisataan di Indonesia (Sunaryo, 2013:1). Pada perkembangannya sektor pariwisata telah memberikan sumbangan terhadap perekonomian daerah yang melaksanakan kegiatan 
pariwisata. Dalam karyanya (Dadi, 2013) menyatakan empat strategis pengembangan pariwisata: pengembangan daya tarik wisata dengan berdasarkan empat pilar 'fourth track strategy', yaitu pembangunan pariwisata diperuntukkan bagi pertumbuhan ekonomi (progrowth), melalui penciptaan lapangan kerja seluas-luasnya untuk masyarakat (pro-job). Selain itu, berpihak pada kepentingan masyarakat kurang mampu (pro-poor) dan pembangunan pariwisata yang ramah lingkungan (pro-environment) termasuk pelestarian nilai-nilai budaya.

Pariwisata pada hakekatnya adalah merupakan perjalanan dari suatu tempat ke tempat lain, bersifat sementara dilakukan perseorangan maupun kelompok, sebagai usaha mencari keseimbangan atau keserasian dan kebahagian dalam lingkungan hidup di dalam dimensi sosial, budaya, alam dan ilmu (Spillane, 1989). Menurut Yoeti, (1996) pariwisata adalah suatu perjalanan yang dilakukan untuk sementara waktu, yang diselenggarakan dari suatu tempat lain, dengan maksud bukan untuk mencari nafkah di tempat yang dikunjungi, tetapi sematamata untuk menikmati perjalanan hidup guna bertamasya dan berkreasi untuk memenuhi keinginan yang beraneka ragam.

Sesuai dengan rekomendasi World Tourism Organization (WTO) dan internasional Union Office Travel Organization, definisi wisatawan mancanegara adalah setiap orang yang mengunjungi suatu negara diluar tempat tinggalnya, didorong oleh satu atau beberapa keperluan tanpa bermaksud memperoleh penghasilan ditempat yang dikunjungi. Definisi ini mencakup dua katagori wisatawan mancanegara, yaitu : a) Wisatawan (tourism) adalah setiap pengunjung seperti definisi tersebut yang tinggal paling sedikit 24 jam, akan tetapi tidak boleh lebih dari 6 bulan ditempat yang dikunjungi dengan maksud kunjungan antara lain: berlibur, rekreasi, dan olah raga, bisnis, mengunjungi teman, misi, menghadiri pertemuan, konferensi, kunjungan dengan alasan kesehatan, belajar dan keagamaan; b) Pelancong (excursionist) adalah setiap pengunjung yang tinggal kurang dari 24 jam ditempat yang dikunjungi (termasuk cruise passangers) yaitu setiap pengunjung yang tiba di suatu negara dengan kapal atau kereta api, dimana mereka tidak menginap di akomodasi yang tersedia di negara tersebut.

Batasan tersebut bisa berlaku wisatawan dalam negeri maupun wisatawan asing, akan tetapi tidak mengandung batasan waktu maupun ruang teritorial yang jelas. Menurut Marpaung (2002:13) menyatakan bahwa pariwisata adalah perpindahan sementara yang dilakukan manusia dengan tujuan keluar dari pekerjaan-pekerjaan rutin, keluar dari tempat kediamannya. Aktivitas dilakukan selama mereka tinggal di tempat yang dituju dan fasilitas yang dibuat untuk memenuhi kebutuhan mereka.

Pariwisata merupakan salah satu jenis industri baru yang mampu mempercepat pertumbuhan ekonomi dan penyediaan lapangan kerja, peningkatan penghasilan, standar hidup serta menstimulasi sektor-sektor produktif lainnya (Pendit, 1999: 32). Pariwisata menjelma menjadi industri pariwisata yang menghasilkan produk-produk wisata untuk dipasarkan. Pengertian industri pariwisata akan semakin jelas apabila kita mempelajarinya dari jasa atau produk yang dihasilkannya, atau pelayanan yang diharapkan wisatawan bilamana ia sedang dalam perjalanan. Melalui tujuan ini akan terlihat tahap-tahap dimana konsumen (wisatawan) memerlukan pelayanan (service) tertentu. Pendekatan ini beranggapan bahwa produk dari industri pariwisata adalah semua jasa yang diberikan oleh macam-macam perusahaan, semenjak seorang wisatawan meninggalkan kediamannya, sampai ketempat tujuan hingga kembali ketempat asalnya. Ditinjau dari segi ekonomi, pariwisata meliputi berbagai macam usaha bisnis besar maupun kecil yang dikenal dengan Industri Pariwisata. Industri pariwisata merupakan industri yang 'menjual atau memperdagangkan pelayanan' kepada mereka yang sedang mengadakan perjalanan (wisatawan). Unsur-unsur pokok dalam industri pariwisata terdiri dari: politik pemerintah, perasaan ingin tahu, sifat ramah tamah, jarak dan waktu, atraksi, akomodasi, pengangkutan, harga-harga, publisitas, promosi dan kesempatan berbelanja yang oleh pemerintah disebut dengan 'Sapta Pesona'. Sapta pesona meliputi yakni keamanan, ketertiban, kenyamanan, keindahan, kebersihan, keramah-tamahan dan Kenangan. Menurut 
Surat Keputusan Menteri Perhubungan Nomor SK.12/K/1971, dalam sektor pariwisata penanaman modal asing ini terbuka dalam bidang akomodasi (hotel), pangan (catering), angkutan pariwisata, objek-objek wisata, rekreasi dan usaha-usaha pariwisata pokok lainnya (Pendit, 1999: 79-80).

Istilah "pariwisata" konon untuk pertama kali digunakan oleh mendiang presiden Soekarno dalam suatu percakapan sebagai padanan dari istilah asing tourism. Pada dasarnya kegiatan yang tidak mendatangkan wisatawan maka kegiatan itu dianggap gagal. Tanpa adanya wisatawan, semua kegiatan pembangunan dan pemugaran objek-objek kebudayan, pembangunan hotel, persediaan angkutan, itu tidak memiliki makna kepariwisataan. Menurut Institute of Tourism in Britain (sekarang Tourism Society in Britain) di tahun 1976 merumuskan : "Pariwisata adalah kepergian orang-orang sementara dalam jangka waktu pendek ke tempat tujuan di luar tempat tinggal dan bekerja sehari-harinya serta kegiatankegiatan mereka selama berada di tempat-tempat tujuan tersebut, mencakup kegiatan untuk berbagai maksud, termasuk kunjungan seharian atau darmawisata/ekskursi" (dalam Pendit, 1999: 30).

Selanjutnya A.J Burkat dan S. Malik dalam bukunya yang berjudul tourism, past, present and future berbunyi, "Pariwisata berarti perpindahan orang untuk sementara dan dalam jangka waktu pendek ke tujuan-tujuan di luar tempat dimana mereka biasanya hidup dan bekerja, dan kegiatan-kegiatan mereka selama tinggal di tempat tujuan itu" (dalam Soekadijo, 2003:3). Sedangkan menurut Professor Salah Wahab (dalam Yoeti, 1995:107) pariwisata adalah suatu aktivitas manusia yang dilakukan secara sadar yang mendapat pelayanan secara bergantian diantara orang-orang dalam suatu negara itu sendiri (di luar negeri) meliputi pendiaman dari daerah lain (daerah tertentu suatu negara atau benua) untuk sementara waktu dalam mencari kepuasan yang beraneka ragam dan berbeda dengan apa yang dialaminya dimana ia bertempat tinggal.

Pengertian kepariwisataan terdapat beberapa faktor penting yang mau tidak mau harus ada dalam batasan atau definisi pariwisata. Faktor-faktor yang dimaksud menurut Yoeti, (1995:109) antara lain:

a. Perjalanan itu dilakukan untuk sementara waktu.

b. Perjalanan itu dilakukan dari satu tempat ke tempat lain.

c. Perjalanan itu walaupun apa bentuknya, harus selalu dikaitkan dengan pertamasyaan atau rekreasi.

d. Orang yang melakukan perjalanan tersebut tidak mencari nafkah di tempat yang dikunjunginya dan semata-mata sebagai konsumen di tempat tersebut.

Berdasarkan faktor-faktor tersebut di atas, beliau memberikan definisi pariwisata sebagai berikut: Pariwisata adalah suatu perjalanan yang dilakukan untuk sementara waktu, yang diselenggarakan dari suatu tempat ke tempat lain, dengan maksud bukan untuk berusaha atau bisnis atau mencari nafkah di tempat yang dikunjungi, tetapi semata-mata untuk menikmati perjalanan tersebut guna pertamasyaan dan rekreasi atau untuk memenuhi keinginan yang beraneka ragam. Diantara berbagai jenis pariwisata yang sudah dikenal (Pendit, 1994 :41) antara lain : (a) wisata budaya, (b) wisata kesehatan, (c) wisata olahraga, (d) wisata komersial, (e) wisata industri, (f) wisata maritim atau bahari, (g) wisata cagar alam, dan (h) wisata bulan madu. Sedangkan berdasarkan motif dan tujuannya Yoeti (1978:114-116) membagi jenis pariwisata ke dalam 6 bagian yaitu: (1) pariwisata budaya, (2) pariwisata pengobatan, (3) pariwisata olahraga, (4) pariwisata dagang dan politik, (5) pariwisata ilmu, (6) pariwisata sosial.

Dalam kegiatan pariwisata tentu harus ada wisatawan sebagai pelaku wisata. Wisatawan ibarat sasaran utama pasar atau konsumen yang sangat penting kedudukannya dalam industri pariwisata. Untuk menarik wisatawan tentu harus ada strategi dan perencanaan 
yang baik dalam usaha untuk mengubah persepsi orang, memodifikasi tingkah laku dan memberikan kesan baik, memberi tahu, membujuk dan mengingatkan. Maka, dalam hal ini diperlukan promosi. Materi yang disuguhkan berupa brocure, tourism map, guidebook, exhibition/pameran dan melalui internet.

\section{Peraturan Daerah Provinsi Kalimantan Tengah Nomor 2 Tahun 2013}

Berdasarkan Peraturan Daerah Provinsi Kalimantan Tengah Nomor 2 Tahun 2013 tentang Rencana Induk Pembangunan Kepariwisataan Provinsi Kalimantan Tengah Tahun 2013-2018, pada bab III pasal 4 (1) huruf a dan b menyatakan pembangunan kepariwisataan meliputi:

\section{Destinasi Pariwisata}

Destinasi pariwisata berdasarkan peraturan daerah tidak menyebutkan pengertian dari destinasi pariwisata namun menjelaskan bahwa destinasi pariwisata provinsi adalah destinasi pariwisata berskala provinsi yang selanjutnya disingkat dengan DPP. Pada pasal 10 (1) DPP ditentukan dengan kriteria:

a. Merupakan kawasan geografis dengan cakupan wilayah kabupaten dan/atau lintas kabupaten yang didalamnya terdapat kawasan-kawasan pengembangan pariwisata nasional yang diantaranya merupakan KSSP;

b. Memiliki daya tarik wisata yang berkualitas dan dikenal secara luas secara provinsi dan nasional, serta membentuk jejaring produk wisata dalam bentuk pola pemaketan produk dan pola kunjungan wisatawan;

c. Memiliki kesesuaian tema daya tarik wisata yang mendukung penguatan daya saing;

d. Memiliki dukungan jejaring aksesibilitas dan infrastruktur yang mendukung pergerakan wisatawan dan kegiatan kepariwisataan; dan;

e. Memiliki keterpaduan dengan rencana sektor terkait.

Dari kriteria diatas pembangunan DPP memiliki unsur salah satunya adalah daya tarik wisata, dalam pasal 11 ayat 1 pembangunan daya tarik wisata meliputi 3 pembangunan daya tari wisata alam, daya tarik wisata budaya, daya tarik buatan manusia. Pada ayat 3 menerangkan arah kebijakan pembangunan daya tarik wisata terdiri dari 3 kawasan yang tersebar pada 14 kabupaten/kota di Provinsi Kalimantan Tengah meliputi: pengembangan kawasan di wilayah barat, wilayah tengah, dan wilayah timur.

\section{Pemasaran Pariwisata}

Pemasaran pariwisata merupakan serangkaian proses untuk menciptakan, mengkomunikasikn, menyampaikan produk wisata, dan mengelola telasi dengan wisatawan untuk mengembangkan kepariwisataan dan seluruh pemangku kepentingan. Pembangunan pemasaran pariwisata daerah meliputi:
a. Pembangunan pasar wisatawan;
b. Pembangunan citra pariwisata;
c. Pembangunan kemitraan pemasaran pariwisata;
d. Pembangunan promosi pariwisata.

\section{Pembangunan Kemitraan Pemasaran Pariwisata}

Berdasarkan Peraturan Daerah Provinsi Kalimantan Tengah Nomor 2 Tahun 2013 menyatakan arah kebijakan pembangunan kemitraan pemasaran pariwisata diwujudkan dalam bentuk pengembangan kemitraan pemasaran yang terpadu, sinergis, berkesinambungan, dan berkelanjutan.

Maksud diatas meliputi meningkatkan:

a. Keterpaduan sinergis promosi antar pemangku kepentingan pariwisata provinsi.

b. Strategi pemasaran berbasis pada pemasaran yang bertanggung jawab yang menekankan tanggung jawab terhadap masyarakat, sumber daya lingkungan dan wisatawan. 


\section{METODE PENELITIAN}

\section{Jenis Penelitian}

Penelitian ini menggunakan metode kualitatif yaitu metode yang mengembangkan konsep-konsep yang dapat menjelaskan makna suatu fenomena yang dikaji. Salah satu prosedur penelitian yang menghasilkan data deskriptif berupa ucapan atau tulisan dan perilaku orang-orang yang diamati (Bagong Suyanto dan Sutinah, 2005:172). Metode kualitatif merupakan proses penelitian yang berkesinambungan sehingga tahap pengumpulan data, pengolahan data, dan analisa data dilakukan secara bersamaan selama proses penelitian. Pendekatan kualitatif diharapkan mampu menghasilkan uraian yang mendalam tentang ucapan, tulisan, dan atau perilaku yang dapat diamati dari suatu individu, kelompok, masyarakat, dan atau organisasi tertentu dalam konteks tertentu yang dikaji dari sudut pandang yang utuh, komprehensif, dan holistic. (Bogdan dan Taylor,1992:21-22).

Metode yang dipakai menjadi bagian penting dalam penelitian ini adalah penelitian kualitatif. Metode yang secara alamiah menghendaki adanya kenyataan sebagai keutuhan yang tidak dapat dipahami jika tidak didasarkan pada konteknya. Dan data yang diperoleh berdasarkan data deskriptif kata-kata tertulis dan lisan tidak berupa prosedur statistik atau bentuk hitungan lainya.

Penelitian ini menekankan pada suatu proses peristiwa dari pada hasil. Proses-proses tersebut yang menggambarkan sebuah peristiwa yang dikaji.

\section{Lokasi Penelitian}

Penelitian ini dilakukan di Kantor Dinas Kebudayaan dan Pariwisata Provinsi Kalimantan Tengah yang terletak di Jalan Tjilik Riwut Km. 5. Subjek penelitian diarahkan pada wisata alam wilayah Kalimantan Tengah dengan pusat perkembangan pariwisata di Kota Palangka Raya yaitu Bukit Tangkiling dan Tugu Soekarno. Berdasarkan lokasi ini penulis dapat menemukan informasi yang dibutuhkan dalam penulisan. Dipilihnya kajian kebijakan pariwisata Kalimantan Tengah dengan pertimbangan bahwa sektor pariwisata saat ini dianggap memilki potensi yang besar dalam rangka meningkatkan Pendapatan Asli Daerah (PAD) Kalimantan Tengah namun belum optimal dikembangkan oleh Pemerintah Provinsi Kalimantan Tengah.

\section{Fokus Penelitian}

Fokus penelitian memuat pokok-pokok dari pengamatan penelitian untuk membatasi masalah atau gejala upaya penyederhanaan terhadap gambaran dari penelitian ini. Yang menjadi fokus penelitian ini adalah:

1. Kebijakan pengembangan pariwisata di Kalimantan Tengah oleh Dinas Kebudayaan dan Pariwisata, dengan penjabaran sebagai berikut:

- Komunikasi (transmisi, kejelasan, konsistensi) dalam pelaksanaan program pembangunan destinasi dan pemasaran pariwisata;

- Sumber Daya (staf, informasi, wewenang, fasilitas) dalam pelaksanaan program pembangunan destinasi dan pemasaran pariwisata;

- Struktur Birokrasi (pengangkatan birokrat, insentif) dalam pelaksanaan program pembangunan destinasi dan pemasaran pariwisata;

- Disposisi (SOPs, Fragmentasi) dalam pelaksanaan program pembangunan destinasi dan pemasaran pariwisata.

2. Faktor penghambat dan faktor pendorong pembangunan destinasi dan pemasaran pariwisata Kalimantan Tengah oleh Dinas Kebudayaan dan Pariwisata. 


\section{PEMBAHASAN}

\section{Kebijakan Publik}

Secara konsep kebijakan publik dipahami sebagai serangkaian tindakan/kegiatan yang diusulkan oleh seseorang, kelompok, atau pemerintah dalam suatu lingkungan tertentu dimana terdapat hambatan-hambatan (kesulitan-kesulitan) dan kemungkinan-kemungkinan (kesempatan-kesempatan) dimana kebijakan tersebut diusulkan agar berguna dalam mengatasinya dan untuk mencapai tujuan yang dimaksud. Friedrich juga menambahkan ketentuannya bahwa kebijakan tersebut berhubungan dengan penyelesaian maksud dan tujuan. Carl Friedrich, (dalam Agustino, 2012:7).

Dengan demikian Peraturan Daerah Provinsi Kalimantan Tengah Nomor 2 Tahun 2013 tentang Rencana Induk Pembangunan Pariwisata Provinsi Kalimantan Tengah adalah bentuk kebijakan public yang disusun dengan maksud untuk mengatasi kesulitan-kesulitan dan hambatan dalam upaya membangun pariwisata Kalimantan Tengah. Kebijakan ini diharapkan menjadi acuan dalam pembangunan pariwisata bagi semua stakeholder. Selain itu keberadaan Ripparprov bermaksud untuk membangunan Kalimantan Tengah menjadi tujuan wisata unggulan di tingkat nasional khususnya dalam bidang wisata alam (ecotourism).

Dalam pengertian yang lain kebijakan public dipahami sebagai serangkaian kegiatan yang mempunyai maksud/tujuan tertentu yang diikuti dan dilaksanakan oleh seseorang aktor atau sekelompok aktor yang berhubungan dengan suatu permasalahan atau suatu hal yang diperhatikan. James Anderson (dalam Agustino, 2012:7). Sekelompok actor yang terkait dalam kajian ini adalah Pemerintah Provinsi, Masyarakat, Pelaku Usaha (ASITA, PHRI, HPI). Mereka masing-masing mempunyai tujuan yang berbeda namun saling berhubungan antara satu dengan lainnya. Industry pariwisata yang maju tidak akan terwujud tanpa didukung oleh keberadaan masyarakat yang sadar wisata dan pelaku usaha yang memiliki produk barang dan jasa yang layak jual. Yang pasti pemerintah provinsi tidak akan mempu berjalan sendiri menggerakkan pariwisata Kalimantan Tengah tanpa bantuan stakeholder yang lainnnya.

\section{Model Implementasi Kebijakan Publik}

Terdapat berbagai model implementasi kebijakan publik yang ada saat ini. Namun peneliti memilih model implementasi kebijakan publik George C. Edward III yang paling sederhana yang terdiri 4 (empat) aspek utama yaitu: aspek komunikasi, aspek sumber daya, aspek disposisi, dan aspek struktur birokrasi.

Aspek komunikasi sebagaimana hasil penelitian tersebut diatas telah memiliki saluran komunikasi yang jelas dan arus informasi berjalan lebih banyak adalah top down ketimbang informasi yang bersifat bottom up. Ini adalah ciri khas dari birokrasi di Indonesia. Konsisten informasi dan komunikasi sedikit terganggu karena mengalami deviasi dalam proses perjalanan disebabkan oleh ketidakmampuan birokrat dalam mencerna kebijakan yang diambil oleh pimpinan. Terkadang ditemukan juga staf (Kepala Seksi) lebih cakap dibandingkan dengan Kepala Bidang. Ada beberapa factor yang mempengaruhi diantaranya factor usia lanjut, latarbelakang pendidikan yang kurang memadai, dan factor kecerdasan.

Aspek sumber daya sebagaimana hasil penelitian tersebut diatas menunjukkan telah memiliki sumber daya manusia yang mencukupi secara jumlah, namun secara kapabilitas masih kurang. Sebagian besar dari para staf hanya mampu melakukan pekerjaan administratif saja (surat menyurat). Sedangkan pekerjaan teknis non administratif seperti kegiatan promosi dianggap masih kurang. Pimpinan dan staf terlalu patuh terhadap aturan yang ada sehingga cenderung statis tidak banyak muncul ide-ide kreatif dalam pengembangan pariwsiata khususnya pemasaran pariwisata. Sarana dan prasarana masih tergolong terbatas karena tidak didukung oleh Sistem Informasi Manajemen Pariwisata yang memadai terbukti ketika diminta data kunjungan wisatawan untuk setiap objek wisata tidak dapat disajikan. 
Aspek Disposisi berdasarkan hasil penelitian tersebut diatas menunjukkan bahwa penempatan birokrat sangat bergantung pada kepala daerah. Kepala Dinas sebagai user tidak memiliki kewenangan untuk menempatkan orang perorang sesuai dengan kapasitas dan kapabilitas. Sehingga sering terjadi gap antara kebutuhan kompetensi dengan orang yang ditempatkan pada posisi yang diharapkan. Tidak berdasarkan pada merried system, lebih kepada memenuhi ketentuan administrasi kepegawaian. Secara praktis muncul fenomena birokrat pangkatnya tinggi tetapi kapasitas dan kapabilitasnya rendah. Selain itu belum tersedia insentif yang jelas bagi para birokrat yang punya kreasi dan inovasi bagi pengembangan pariwisata Kalteng. Sehingga tidak heran para birokrat bekerja cenderung monoton.

Aspek Struktur Birokrasi berdasarkan hasil penelitian tersebut diatas menunjukkan bahwa sebagian kegiatan pemasaran telah memiliki SOP yang biasa disebut dengan kerangka acuan kerja. Sedangkan bidang pengembangan destinasi pariwisata masih belum ada kerangka acuan kerja. Hal ini kemungkinan karena pengembangan destinasi pariwisata bobotnya lebih berat dan lebih banyak melibatkan stakeholder khususnya pemerintah daerah kabupaten/kota. Penyebaran tanggung jawab telah dilakukan tetapi "Gayung Belum Bersambut". Pemerintah daerah kabupaten/kota belum menerima informasi secara jelas tentang Rencana Induk Pembangunan Pariwisata Provinsi Kalimantan Tengah. Dokumen Perda No. 2 Tahun 2013 baru diterima oleh Disbudpar kabupaten/kota pada akhir tahun 2014. Bentuk penyebaran tanggung jawab pengembangan pariwisata Kalimantan Tengah adalah kewenangan dalam menyusun Ripparkot/Ripparkab sesuai potensi daerah masing-masing.

\section{Pariwisata}

Secara konsep pariwisata dipahami sebagai adalah suatu perjalanan yang dilakukan untuk sementara waktu, yang diselenggarakan dari suatu tempat lain, dengan maksud bukan untuk mencari nafkah di tempat yang dikunjungi, tetapi semata-mata untuk menikmati perjalanan hidup guna bertamasya dan berkreasi untuk memenuhi keinginan yang beraneka ragam. (Yoeti, 1996). Dari konsep pariwisata tersebut dapat dimaknai bahwa kegiatan pariwisata harus menyuguhkan kenikmatan. Kenikmatan selama perjalanan, kenikmatan dalam pemandangan, kenikmatan beristirahat, dan juga kenikmatan berbelanja. Mungkin sebagian besar objek wisata alam di Kalimantan Tengah ini belum mampu menyuguhkan semua kenikmatan tersebut. Meski pemandangan alam kita cukup mempesona. Satu objek wisata yang menjadi unggulan Pemerintah Provinsi Kalimantan Tengah adalah Taman Nasional Tanjung Puting. Lokasi yang terletak di Kabupaten Kotawaringin Barat tersebut telah menyuguhkan fenomena alam yang begitu indah dan alami. Selain itu sarana dan prasarananya sudah sangat mendukung dan berstandar internasional. Lokasi yang lain seperti Taman Nasional Sebangau masih belum memiliki standar yang sama. Ada banyak persoalan yang melatarbelakangi. Diantaranya adalah lokasinya berada di 3 (tiga) kota yaitu Kota Palangka Raya, Kabupaten Pulang Pisau, dan Kabupaten Katingan. Sehingga ada kemungkinan ketiga pemerintah daerah tersebut saling menunggu untuk mengambil peran dalam mengembangkan Taman Nasional Sebangau. Begitu juga nasib objek wisata lainnya, masih menunggu sentuhan dari para stakeholdernya. Entah sampai kapan hal tersebut bisa terealisasi.

\section{Pemasaran dan Promosi Pariwisata}

Ada beberapa kegiatan pokok yang harus dilakukan dalam pemasaran diantaranya:

a. Memahami kebutuhan pasar wisatawan secara baik. Hal ini sebenarnya sudah dilakukan oleh Disbudpar Kalteng, akan tetapi tidak terdokumentasi dengan baik sehingga tidak pernah dilakukan corrective action (perbaikan).

b. Mengembangkan produk wisata yang mempunyai nilai superior di mata pasar wisatawan. Dukungan terhadap pengembangan produk wisata masih berjalan parsial, belum ada kerjasama yang berkesinambungan antara Disbudpar, Disperindag, dan pelaku usaha 
kerajinan. Insentif yang diberikan kepada pelaku usaha hanya berupa kesempatan mengikuti pameran/ekspo. Bantuan permodalan belum pernah diberikan.

c. Mendistribusikan informasi produk wisata ke wisatawan secara tepat dan menarik. Hal ini sudah dilakukan dengan membidik daerah atau kota-kota yang potensial seperti Jakarta, Surabaya, Bali, Jogja, dan Batam dengan mempertimbangkan konektivitas penerbangan.

d. Memproduksikan produk wisata dengan efektif. Hal ini juga sudah dilakukan dengan mengembangkan produk-produk wisata khas Kalteng seperti kerajinan batu, kerajinan batik, dan makanan khas Kalteng.

Promosi dimaknai sebagai membujuk atau mengingatkan secara khusus kepada orang lain, dalam hal ini pembeli atau calon pembeli. Seperti dijelaskan oleh Alma dimana dalam mempengaruhi mereka diperlukan beberapa tahapan melalui media komunikasi, seperti: (a) pendekatan melalui kontak dengan manusia, (b) media elektronik (TV, radio dan lain-lain), dan (c) media cetak. Kegiatan a, b, dan c tersebut telah dilaksanakan semua. Namun saat ini kegiatan tersebut diatas masih belum cukup jika tidak didukung informasi promosi yang berbasis internet. Sehingga informasi promosi tersebut dapat lebih mudah dan lebih luas diterima oleh masyarakat tidak hanya di Indonesia tapi di seluruh dunia. Namun saying media promosi tersebut hingga saat ini belum terealisasi.

\section{Destinasi Pariwisata}

Undang-Undang Nomor 10 Tahun 2009 tentang kepariwisataan menyebutkan bahwa destinasi pariwisata adalah kawasan geografis yang berada dalam satu atau lebih wilayah administratif yang di dalamnya terdapat daya tarik wisata, fasilitas umum, fasilitas pariwisata, aksestabilitas, serta masyarakat yang saling terkait dan melengkapi terwujudnya kepariwisataan. Berdasarkan definisi tersebut dapat dijelaskan oleh peneliti berdasarkan hasil penelitian tersebut diatas bahwa cukup objek wisata alam di Kalimantan Tengah, akan tetapi hanya memiliki daya tarik wisata saja belum didukung oleh fasilitas umum, fasilitas pariwisata, aksestabilitas, masyarakat yang sadar pariwisata dan mendukung kegiatan pariwisata. Banyak sekali objek wisata yang masih "merana" bisa juga dikatakan "perawan", karena belum dikelola dengan baik oleh Pemerintah Provinsi ataupun Pemerintah Daerah Kabupaten/Kota. Bahkan pemerintah provinsi pun belum menetapkan objek wisata mana saja yang menjadi objek wisata resmi atau Destinasi Pariwisata Provinsi (DPP) sebagaimana diatur dalam Ripparprov.

\section{Peraturan Daerah Provinsi Kalimantan Tengah Nomor 2 Tahun 2013}

Pembangunan kepariwisataan provinsi meliputi: Destinasi pariwisata, pemasaran pariwisata, industry pariwisata, dan kelembagaan pariwisata. Pembangunan Destinasi Pariwisata diyakini memerlukan waktu yang panjang karena harus melibatkan pemerintah daerah kabupaten/kota. Pembagian wilayah/kawasan wisata di Kalteng dibagi menjadi 3 (tiga) yaitu: wilayah barat (Kobar dan sekitarnya), wilayah tengah (Palangka Raya dan sekitarnya), dan wilayah timur (Barito Selatan dan sekitarnya). Ketiga wilayah tersebut menjadi pusat pengembangan pariwisata Kalimantan Tengah. Dan saat ini yang sudah menjadi unggulan adalah wilayah barat yaitu adanya Taman Nasional Tanjung Putting.

Pembangunan pemasaran pariwisata daerah meliputi: pembangunan pasar wisatawan, pembangunan citra pariwisata, pembangunan kemitraan pariwisata, dan pembangunan promosi pariwisata. Kesemua indikator tersebut telah dilaksanakan oleh Pemerintah Provinsi Kalimantan Tengah namun belum terlihat serius dan berkesinambungan. Biasanya yang terlihat hanya kegiatan rutin saja seperti Festival Budaya Isen Mulang dan Kalteng Expo. Kedua kegiatan tersebut rutin dilaksanakan tetapi tidak memberikan kontribusi berkelanjutan bagi pembangunan pariwisata Kalimantan Tengah. Cenderung sebagai kegiatan hiburan saja. 
Tabel 4.1

\begin{tabular}{|c|c|c|c|}
\hline \multicolumn{4}{|c|}{ Pelaksanaan Program Pembangunan Destinasi dan Pemasaran Pariwisata } \\
\hline No & Bidang & Program/Kegiatan & Sasaran \\
\hline 1. & Pembangunan Destinasi & $\begin{array}{l}\text { - Menyediakan sarana pendukung } \\
\text { seperti (jalan, penginapan, } \\
\text { rumah makan, tempat hiburan) } \\
\text { - Menyediakan alat transportasi: } \\
\text { mobil angkutan umum, kapal } \\
\text { susur sungai, dll } \\
\text { - Menyediakan prasarana listrik } \\
\text { dan air bersih } \\
\text { - Mendorong daerah } \\
\text { kabupaten/kota menetapkan } \\
\text { Destinasi Pariwisata } \\
\text { Kabupaten/Kota (DPK) }\end{array}$ & $\begin{array}{l}\text { Masyarakat } \\
\text { sekitar, pelaku } \\
\text { usaha, } \\
\text { pemerintah } \\
\text { daerah } \\
\text { setempat }\end{array}$ \\
\hline 2. & $\begin{array}{l}\text { Pembangunan Pemasaran } \\
\text { Pariwisata }\end{array}$ & $\begin{array}{l}\text { - Melaksanakan kegiatan MICE } \\
\text { (Meeting, Incentive, } \\
\text { Convention, Exhibition) baik } \\
\text { lokal, nasional, maupun } \\
\text { internasional } \\
\text { - Mencetak booklet, leaflet, } \\
\text { majalah, brosur } \\
\text { - Membangun website khusus } \\
\text { pariwisata Kalteng } \\
\text { - Menyediakan insentif bagi } \\
\text { pelaku usaha berupa: fasilitas } \\
\text { tiket, dan akomodasi untuk ikut } \\
\text { even nasional } \\
\text { - Mendorong pemerintah daerah } \\
\text { kabupaten/kota mendorong } \\
\text { website khusus promosi } \\
\text { pariwisata }\end{array}$ & $\begin{array}{l}\text { Masyarakat } \\
\text { sekitar, pelaku } \\
\text { usaha, } \\
\text { pemerintah } \\
\text { daerah } \\
\text { setempat }\end{array}$ \\
\hline
\end{tabular}

Sumber: Data Diolah

\section{KESIMPULAN}

Berdasarkan hasil penelitian dan pembahasan pada bab sebelumnya maka dapat ditarik kesimpulan bahwa:

1. Pelaksanaan program pembangunan destinasi dan pemasaran pariwisata Kalimantan Tengah oleh Dinas Kebudayaan dan Pariwisata telah terlaksana berlandaskan pada Perda No. 2 Tahun 2013 tentang Rencana Induk Pembangunan Pariwisata Provinsi Kalimantan Tengah. Keberlanjutan pelaksanaan program pembangunan destinasi dan pembangunan pemasaran pariwisata terhalang oleh belum tersedianya Ripparkab/Ripparkot di seluruh kabupaten/kota di Kalimantan Tengah. Hanya ada 2 (dua) objek wisata yang menjadi unggulan dalam pelaksanaan program pembangunan destinasi dan pembangunan pemasaran pariwisata, yaitu obyek wisata Taman Nasional Tanjung Puting dan Taman Nasional Sebangau.

2. Faktor penghambat dan faktor pendorong pelaksanaan program pembangunan destinasi dan pemasaran pariwisata Kalimantan Tengah oleh Dinas Kebudayaan dan Pariwisata muncul dari internal Dinas Kebudayaan dan Pariwisata dan juga dari pihak eksternal seperti Pemerintah Daerah Kabupaten/Kota. Faktor penghambat diantaranya belum 
terwujud program promosi pariwisata yang berbasis internet, selain itu juga belum terciptanya masyarakat yang sadar wisata. Faktor pendorong utama adalah keberadaan pelaku usaha seperti ASITA, PHRI, dan HPI yang sudah sangat mendukung pengembangan pariwisata Kalimantan Tengah.

\section{DAFTAR PUSTAKA}

Agustino Leo (2006), Dasar-Dasar Kebijakan Publik, diakses pada tanggal 9 Februari 2015, situs World Wide Web.

Agustino, Leo, 2012, Dasar-Dasar Kebijakan Publik, Bandung, Cet. 3, Alfabeta.

Fakultas Ilmu Sosial Dan Ilmu Politik, Universitas Palangka Raya. 2013. Buku Pedoman Penulisan Skripsi: Jurusan Ilmu Pemerintahan. Palangka Raya.

Marpaung, Happy. 2002. Pengetahuan Kepariwisataan. Bandung: Alpabeta.

Nugroho Riant, 2009, Public Policy, Jakarta, Edisi Revisi, Elex Media Komputindo.

Pendit Nyoman S., 2006, Ilmu Pariwisata, Jakarta, Cet. 8, Pradnya Paramita.

Pendit, Nyoman S. 1995. Ilmu Ekonomi Pariwisata Sebuah Pengantar. Jakarta: PT. Pradnya Paramita.

Peraturan Daerah Nomor 2 Tahun 2013 Tentang Rencana Induk Pembangunan Kepariwisataan Provinsi Kalimantan Tengah.

Peraturan Pemerintah Nomor 50 Tahun 2011 Tentang Rencana Induk Pembangunan Pariwisata Nasional.

Soekadijo, R.G. 2000. Anatomi pariwisata: memahami pariwisata sebagai "systemic linkage". Jakarta: Gramedia

Sukarsa, I Made. 1999. Pengantar Pariwisata. Departemen Pendidikan dan Kebudayaan Direktorat Jenderal Pendidikan Tinggi Badan Kerjasama Perguruan Tinggi Negeri Indonesia Timur.

Sunaryo Bambang, 2013, Kebijakan Pembangunan Destinasi Pariwisata,Yogyakarta, Cet. 1, Gava Media.

Suyanto Bagong, Sutinah, 2005, Metode Penelitian Sosial, Jakarta, Edisi I, Kencana.

Undang-Undang Nomor 10 Tahun 2009 Tentang Kepariwisataan.

Warpani Suwardjoko P. dan Indira P. Warpani, 2007, Pariwisata Dalam Tata Ruang Wilayah, Bandung, ITB.

Widodo (2011), Faktor-Faktor Implementasi Kebijakan, diakses pada tanggal 12 Februari 2015 situs World Wide Web http://arenakami.blogspot.com/2012/06/implementasikebijakan-george-edward.html.

Widodo Joko, 2006, Analisis Kebijakan Publik, Malang, EdisiPertama, Bayumedia Publishing.

Yoeti, H. Oka A. 2002. Perencanaan Strategis Pemasaran Daerah Tujuan Wisata. Jakarta: Pradnya Paramita. 